\title{
THE UNITED NATIONS INSTITUTE FOR TRAINING AND RESEARCH UNITAR
}

In der Reihe von Institutionen, die für die Entwicklungspolitik und Entwicklungsforschung von Bedeutung sind, geben wir diesmal dem United Nations Institute for Training and Research (UNITAR) Gelegenheit zu einer Selbstdarstellung. Im Anschluß daran veröffentlichen wir einen Bericht über die Forschungsarbeit dieser Institution auf dem Gebiet der friedlichen Beilegung von Konflikten.

The United Nations Institute for Training and Research (UNITAR) owes its existence to the long-felt need within the United Nations community for a central institution which will undertake studies and research on the problems of the United Nations and also to impart training in selected areas of concern to the United Nations. The need for such an institution was expressed, among others, by the late Secretary-General, Dag Hammarskjöld. With the launching of the first development decade, many member states expressed concern at the lack of training facilities within the United Nations system, particularly for the personnel of developing countries which had no advanced training institutions in the areas of diplomacy and technical cooperation. Within the technical assistance area, the United Nations had already begun ad-hoc training programmes for foreign service officials of developing countries. Similarly, training activities had been initiated for national coordinators of technical assistance programmes. Member states had also pointed out the need for a central training establishment for the international civil service. These diverse ideas began crystallizing in 1963 and the General Assembly of the United Nations, on the recommendation of its Economic and Social Council, requested the Secretary-General to study the organisational and financial requirements for the creation of a United Nations training and research institute. The Secretary-General, having studied various possibilities, submitted a report which formed the basis for the establishment of the Institute in 1964 under General Assembly Resolution 1934 (XVIII) of 11 December 1963.

Even though the Statute governing the activities of the Institute was promulgated by the Secretary-General in November 1965, the Institute began functioning in March 1965 with the constitution of a Board of Trustees, the appointment of an Executive Director, the availability of a separate premises for the Institute within the area of the United Nations Headquarters and the creation of a nucleus of staff.

UNITAR is a unique institution within the United Nations family. It is part of the United Nations system yet it is an autonomous organisation with independent authority to take decisions in regard to its programme of activities and its financing. This is made possible by making the Institute dependent on voluntary contributions from governments, non-governmental organisations, private foundations and individuals. Though an organisational structure dependent on voluntary contributions is not a novelty in the United Nations family, certain other characteristics and attributes of the Institute, by virtue of its Statute and terms of the General Assembly resolutions, provide the Institute with a large degree of autonomy and flexibility - two vital requirements for carrying out objective and specialised programmes of research and training. 
As an autonomous institution within the framework of the United Nations, the purpose of the Institute is to enhance, through research and training, the effectiveness of the United Nations in achieving the major objectives of the Organisation, in particular, the maintenance of peace and security and the promotion of economic and social development. A Board of Trustees, composed of distinguished diplomats, international officials and scholars from 20 countries, controls the functioning of the Institute by formulating the principles and policies which govern the activities and operations of the Institute and by considering and approving the work programme and budget of the Institute. Under the guidance of the Board of T'rustees, the Executive Director has overall responsibility for the organisation, direction and administration of the Institute in accordance with the general policies formulated by the Board. The two Executive Directors of the Institute, Mr. Gabriel d'Arboussier - (1965 to 1967) at present Ambassador of Senegal to the Federal Republic of Germany, and Chief S. O. Adebo (since March 1968 - before joining UNITAR Chief Adebo was the Permanent Representative of Nigeria to the United Nations since 1962) have built up the Institute into a respected and useful organisation rendering valuable services to the United Nations family of organisations and the member states, especially the developing countries. The important, but difficult, responsibilities of the Executive Director include the generation of adequate funds through voluntary contributions, the creation of a significant and constructive programme of training and research and the recruitment of an internationally competent staff consisting of scholars from diverse disciplines and with wide experience in academic institutions and international organisations.

Financial resources and the services of competent research and training staff have been the two main issues faced by the Institute from its very inception. Considering that these two problems are met with by all independent organisations carrying out research and training both at the national and international levels, the Institute can take some encouragement from the creditable manner in which both these difficult issues have been tackled by the Executive Directors and their senior officials. The founding fathers of the Institute wanted that it should remain a small but compact outfit concentrating its resources on selected important problems of immediate interest to the United Nations system. This objective has been the main guideline for the formulation of its training and research programmes.

The dominant emphasis of its research programme is on the enhancement of the capabilities of the United Nations and its related organisations bearing in mind a definite and unique range of responsibilities and capabilities inherent in its constitution and its place within the United Nations system. The research studies already carried out or in progress are: Methods and Criteria of evaluation of United Nations assistance programmes; The Problems of Small States; The Wider Acceptance of Multilateral Treaties; Peaceful Settlement of Disputes by the United Nations; Transfer of Technology to Developing Countries; The Brain Drain; the Relationship between the United Nations and Regional Inter-governmental organisations, and the Use of Information on the United Nations by the mass media. The future research activities of UNITAR will continue to have the same emphasis around the three main themes of United Nations functioning and procedures, peace research, and economic and social development. Apart from substantive research studies, the Institute functions as a centre for the promotion and encour- 
agement of research on the United Nations by scholars and research institutions in all parts of the world. This is achieved partly through holding periodic meetings attended by diplomats, international officials and scholars, and through the organisation of regional seminars. The research activities of the Institute have been guided by a distinguished international official and legal scholar, Mr. Oscar Schachter, who is Director of Research and Deputy Executive Director. He is assisted by a staff of research scholars including Professor Alexander Szalai, a member of the Hungarian Academy of Sciences and at present the Deputy Director of Research, UNITAR.

The training activities of the Institute have been planned and carried out within the statutory function which states that the Institute shall provide training at various levels for assignments with the United Nations or the specialised agencies and for assignments in their national services which are connected with the work of the United Nations, the organisations related to it or other institutions operating in related fields. These programmes may include training for staff members of the United Nations and of the specialised agencies as well as training for special United Nations field assignments. The Institute's training activities have been built around three main areas - (1) training for diplomats at the United Nations and other foreign service officials from developing countries (2) training of national and international officials connected with the United Nations development activities (3) International Law and related questions. In carrying out these central core of training responsibilities, the Institute has organised basic training courses, advanced seminars, special programmes such as colloquia and lectures, and different kinds of fellowships and internships. These programmes have been implemented through centralised courses at the Headquarters of the United Nations and also through regional programmes in Africa, Asia, Latin America and the Middle East. The training department is now under the leadership of Mr. Jean Taupin, a former senior official of the United Nations Development Programme. $\mathrm{He}$ is assisted by a team consisting of former ambassadors and senior officials of international organisations. The Institute also invites distinguished scholars as special lecturers and seminar leaders.

Apart from the financial and human resources determining the extent and pace of the Institute's activities, an important aspect has been the network of coordination and cooperation which the Institute has built up with international and non-governmental organisations, academic and research institutions in every part of the world, and individual scholars and wellwishers of the United Nations. The Institute looks forward to a continuation of its programmes on the same scale and with the same emphasis as in the first five years of its existence. While it is difficult to assess the impact and usefulness of the Institute's activities, the general appreciation and support given to the Institute by governments and private institutions are manifestations of the confidence the international community places in the Institute and the usefulness of its services which the United Nations system and the member states expect from UNITAR. This confidence and expectation would remain the main basis for the continued vigour and existence of UNITAR.

Joseph J. Therattil 